\title{
A legalização da classe operária, de Bernard Edelman
}

[EDELMAN, Bernard. A legalização da classe operária.

Tradução coordenada por Marcus Orione. São Paulo: Boitempo,

2016, 192 p.]

Caio Henrique Amaro ${ }^{1}$

Ao concluir que a revolução havia fracassado e o comunismo havia perdido a partida para o capitalismo, segundo suas próprias palavras, o jurista e filósofo francês Bernard Edelman, ao invés de se resignar, formulou uma crítica com o intuito de rever seus conceitos e ir contra o "lugar comum" da teoria marxista, defendendo, essencialmente, a tese de que, embora as condições de trabalho melhorassem com o tempo, as conquistas operárias consistem em derrotas políticas.

Através de um diálogo aberto, proposto em seu prefácio, em 2015, Edelman relembra o contexto histórico que o motivou a publicar a Legalização da classe operária em 1978. O fim de sua crença no advento do comunismo e na luta ideológica contra o capital serviram de energia motriz para a publicação de sua abordagem peculiar sobre a ilusão da luta de classes. Analisando, no cenário francês da década de 1980, as disposições do contrato de trabalho do empregado que o transformou em um homem de mercado, percebeu que, como Marx previra, os homens passaram a transformar em objeto de troca tudo aquilo que consideram inalienáveis, e a forma jurídica, por sua vez, passou a inibir a luta de classes.

1 Acadêmico do curso de direito da UNISOCIESC - Joinville,SC e participante do Grupo de Estudo e Pesquisa Direito e Ideologias (GEPDI) 
Referindo-se a Althusser constantemente, Edelman elabora a proposta de analisar os efeitos da luta de classes enclausurada nos aparelhos ideológicos de Estado. Diante disso, define que o único poder que a lei burguesa pôde conferir à classe operária através da história é o poder burguês (p. 19). Deste modo expõe o equívoco da expectativa de um direito operário em oposição ao direito burguês, assim como Pachukanis, a sua época, evidenciou a ilusão dos juristas soviéticos na concepção de um "novo direito".

Primeiramente, propõe um debate a relação sobre subsunção da classe operária ao poder jurídico do capital, este que, manifestado pelo contrato com o empregador, aliena a força de trabalho em troca de um salário, enquanto sua força é incorporada juridicamente via propriedade privada.

Por conseguinte, o autor encontra nas indagações sobre a greve, e sua forma jurídica, um importante fato gerador de antinomia: a greve geraria ou não o rompimento no contrato de trabalho? Retomados em diversos momentos na narrativa, os efeitos que ambas as respostas causam no âmbito jurídico são questões de discussão quanto à regulamentação da classe operária. Acrescenta que a alternativa adotada pelos juristas humanistas fora a adição da greve ao contrato de trabaIho, sendo permitida, desde que não haja abuso.

A construção linear de Edelman passa então a tratar da problemática caracterização desse "abuso", sendo classificada como a violência de classe, a mesma que tornaria a greve eficaz. Consequentemente, a mesma violência não pode ser contratualizada, pois é prejudicial ao funcionamento da empresa e implicaria a revelação de que os operários são os verdadeiros donos dos meios de produção (p. 47). Também deixa o direito de reconhecer o aspecto político da greve, apesar dela, sendo uma manifestação coletiva, expressar-se como um ato de poder, logo, um ato político (p. 60) e, destarte, inadmissível pela imposição da neutralidade política no interior das empresas.

Neutralidade esta, que, para ser mantida, ignora a violência e a dominação de classes (p. 72) e contamina os "embriões do poder operário" dentro da empresa, exemplificados em comitês. Tais instituições 
representativas reproduzem a ideologia internamente (p. 83) pela disseminação de uma cultura geral, envolta no aspecto humanista que por intermédio da ordem jurídica dissemina uma inversão onde a atividade dos homens é o motor da história ao invés da luta de classes (p. 86).

Salienta que, por mais que os sindicatos estejam legalizados pela lógica burguesa do patronato, as massas não obedecem os líderes sindicais da mesma forma que funcionários obedecem seus superiores (p. 111). Origina-se, portanto, uma falha jurídica, pois na eminência dessa relação de subordinação, cita-se o dirigente sindical para contraditório em um processo judicial por abuso de greve, porém como poderia este representar grevistas não sindicalizados? Ou, por outro lado, como haveria um representante legal para um ato que, por conter abuso, é ilegal?

Diante de tantos impasses surge uma resolução a favor da paz social, legalmente o objetivo dos empresários e dos grevistas, somente possível mediante da figura da "discussão". A greve e o próprio sindicato passam a ser caracterizados em prol da negociação, externando uma situação onde os grevistas podem legalmente ocupar o local de trabalho. Desta forma os sindicatos ganhariam força para promover a discussão com os patronatos que, por sua vez, têm a possibilidade de não aderir às requisições e chamar a polícia a fim de garantir seu direito a propriedade, enquanto o Estado aplaudiria seu "novo direito" funcionando (p. 133). A luta de classes seria impossibilitada pelos procedimentos de negociação e a classe operária estaria submissa à gestão capitalista (p. 139). Não bastassem tais medidas, Edelman mostra como a Corte de Cassação conferiu aos patrões o benefício da medida liminar contra os assalariados, trazendo, além de mais poder ao sistema burguês, contradições quanto o direito de ocupação.

Em uma conclusão repleta de desabafos, Edelman consegue regatar a sensação transmitida em seu prefácio, elencando suas duas ilusões perdidas: a crença na existência da classe operária, inibida pelo Estado de direito que distribui e organiza seus espaços por competência e representação, fazendo com que a classe operária desapareça; e a ilusão jurídica de que a liberdade pode ser transformada em direito. 
Após a formulação de todo seu argumento, deixa ao leitor, com quem tanto conversou, a interpretação livre dos discursos do ex-secretário geral adjunto do Conselho da Europa e de um professor de direito soviético em situações econômicas e período distintos. As semelhanças falam por si, as esperanças compartilhadas de um direito emancipatório evidenciam o ponto de Edelman de que o direito humanista é correlato ao "novo direito" soviético e continua a reproduzir o discurso burguês. Enfim, os anexos, notas e documentos do comitê nacional do patronato francês presentes no final da edição, embora isentos de comentários do autor, acrescentam e servem de exercício analítico das opiniões sob a ótica apresentada ao longo da obra.

$\mathrm{O}$ argumento de Edelman possui dois grandes aliados que contribuem para sua contemporaneidade: a fluidez do texto, uma vez que o autor literalmente conversa com o leitor ao longo das páginas, não deixando de lado a constante ironia, utilizada como artifício eficaz de exposição das diversas contradições que pretende demonstrar em uma conversa envolta em sinceridade, prevendo pontos polêmicos, logo rebatidos no capítulo seguinte, estabelecendo uma conexão lógica que contribui para a construção de seu pensamento; e a ampla exemplificação, contida nas situações, decisões e resoluções doutrinárias da época, que se mostram surpreendentemente atuais, uma vez que o patronato perdura e o direito burguês continua a regular os movimentos sociais.

A Legalização da classe operária traz a nítida vontade de Bernard Edelman em transmitir seu desencanto com as supostas conquistas operárias. Com uma linguagem clara e objetiva, confere ao leitor uma reflexão crucial para a crítica da reprodução do capital e da predominância do direito burguês não apenas na mediação da realização do mais-valor, mas, inclusive, na contratualização e neutralização das formas de resistência dos trabalhadores. 